\title{
General geology and geochemistry of the Lokpanta Formation oil shale, Nigeria
}

\author{
Sylvester Ofili ${ }^{\left(\mathrm{a}^{*}\right.}$, Alvar Soesoo ${ }^{(\mathrm{a}, \mathrm{b})}$
}

(a) Department of Geology, Institute of Ecology and Earth Sciences, University of Tartu, Ravila 14a, 50411 Tartu, Estonia

(b) Institute of Geology, Tallinn University of Technology, Ehitajate tee 5, 19086 Tallinn, Estonia

Received 16 April 2020, accepted 25 January 2021, available online 10 March 2021

\begin{abstract}
A detailed geochemical and mineralogical study was carried out on the Lokpanta oil shale (OS), Nigeria. Samples from three drill cores and several outcrops were studied in order to understand OS general geochemistry and reconstruct tectonic and depositional settings as well as paleoredox conditions. The mineral phases in OS include calcite, quartz, dolomite, feldspar, illite, kaolinite, halloysite, pyrite and gypsum, as well as a trace amount of anatase. The Lokpanta oil shale shows little variation in geochemistry. It is depleted in trace elements $B a$ and $R b$ and major compounds except $C a O$, and is enriched in trace elements $\mathrm{Mo}, \mathrm{Sb}, \mathrm{As}, \mathrm{V}, \mathrm{Zn}, \mathrm{Ni}$ and $U$ with reference to the PostArchean Australian Shale (PAAS). These enrichments are, however, in most cases lower than those in the Estonian graptolite argillite (GA). Trace element ratios $(\mathrm{U} / \mathrm{Th}, \mathrm{Ni} / \mathrm{Co}, \mathrm{V} / \mathrm{Ni}, \mathrm{V} /(\mathrm{V}+\mathrm{Ni}) \mathrm{V} /(\mathrm{V}+\mathrm{Cr}))$ indicate that the Lokpanta oil shale was deposited in an anoxic environment. Discriminant diagrams also suggest its deposition in an active continental margin setting and a transitional to marine environment. The geochemical and paleoenvironmental features of the Lokpanta oil shale were compared with those of the Estonian graptolite argillite.
\end{abstract}

Keywords: Lokpanta Formation oil shale, geochemistry, paleoenvironment, redox conditions.

\section{Introduction}

Oil shale (OS) occurs in all continents of the world, amounting to over 690 billion tons of in situ shale oil. In comparison with conventional oil, OS resources worldwide are four times as high [1]. However, currently unconventional OS resources are exploited far less than conventional hydrocarbon resources. A major reason for this is the high cost of oil production and the negative impact of oil shale exploitation on the environment.

\footnotetext{
* Corresponding author: e-mail sylvester.ofili@ut.ee

(C) 2021 Authors. This is an Open Access article distributed under the terms and conditions of the Creative Commons Attribution-NonCommercial 4.0 International License (http://creativecommons.org/licenses/by-nc/4.0/).
} 
The largest deposits are found in the United States of America and are estimated to account for up to $80 \%$ of the world oil shale resource [1]. Other countries with major deposits include China, Russia, Brazil, Morocco, Jordan and Estonia.

At present, there is more interest in utilizing oil shale resource for shale oil production than for other purposes. But the fact is that oil shale can be as beneficial in heat and electricity generation as in shale oil production. The former has been proven by the Estonian oil shale sector where until recently about $90 \%$ of electricity was generated by combustion of OS in power plants. Estonia very likely had the most developed oil shale technology in the world. But due to environmental restrictions and political attention, oil shale combustion for heat and electricity generation has drastically decreased starting 2019, whereas the European Green Deal is exerting great pressure on oil shale industry in this respect.

In Nigeria, oil shale was discovered in 1990 in Lokpanta, Imo State (now Abia State), but it has remained unexploited to date and very little is known about its geology [2]. This is mainly because there are huge reserves of conventional hydrocarbon resources worldwide. However, with the country's declining petroleum reserves and persistent electricity generation challenges, there is hope that oil shale will serve as a complementary resource of energy in the future.

The Lokpanta deposit is the only oil shale deposit discovered in Nigeria so far. It is situated in the Abakaliki depocenter of the Lower Benue Trough and covers an area of $72.7 \mathrm{~km}^{2}$ (Figs. 1a and 1b). Based on foraminiferal and ostracod biostratigraphy, the Lokpanta OS is believed to have been deposited in the outer shelf to the bathyal environment, and is assigned to the Late Cenomanian to the Early Turonian age [4]. It is characteristically of dark grey to black colour, platy and calcareous with inoceramus moulds (Figs. 2a and 2b). The oil shale alternates with marl units which are lighter in color. Being historically regarded as a facies of the Eze-Aku shale, it was recently proposed that the Lokpanta oil shale should be a Formation instead (see Discussion).

Plots of $\mathrm{MgO}$ vs $\mathrm{MnO}, \mathrm{MgO}$ vs $\mathrm{Fe}_{2} \mathrm{O}_{3}+\mathrm{FeO}$ and $\mathrm{CaO}$ vs $\mathrm{P}_{2} \mathrm{O}_{5}$ have been used to distinguish the Turonian shale from Albian shales in the Benue Trough [5]. The Lokpanta deposit is easily identified by the presence of pyrite nodules and oil smell [6]. In the field, OS outcrops are usually low-lying and mostly highly weathered.

Organic geochemical assessment indicates the oil shale's excellent petroleum potential, high organic matter $(\mathrm{OM})$ content and kerogen type II/III, capable of generating oil and gas [6]. The regional anoxic event (OAE 2), which occurred during the Cenomanian/Turonian, did indeed play a significant role in the deposition of a large quantity of organic matter.

The Lokpanta oil shale has the total organic carbon (TOC) range of 3.5 to $7 \%$ and the average Hydrogen Index (HI) value of $332 \mathrm{mg} \mathrm{HC} / \mathrm{g} \mathrm{TOC}$, with the total hydrocarbon yield $(\mathrm{S} 1+\mathrm{S} 2)$ ranging from 13 to $25 \mathrm{mg} \mathrm{HC} / \mathrm{g}$ rock $[2,7]$. 


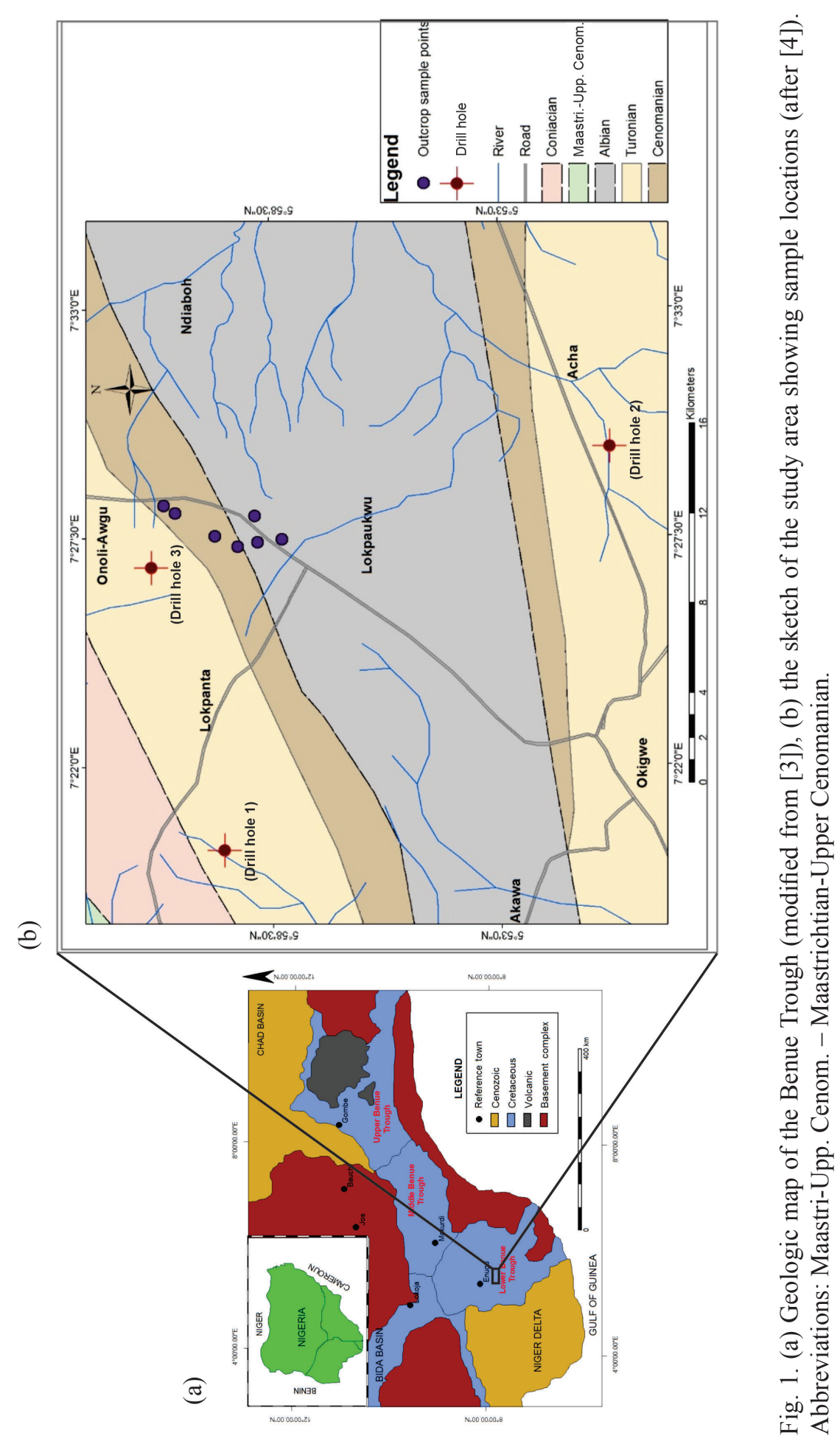


(a)

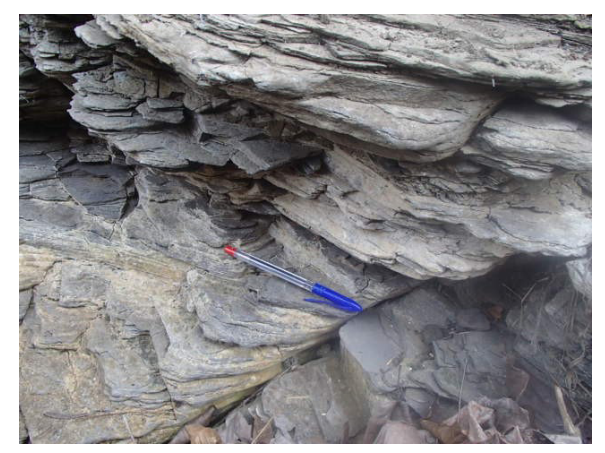

(b)

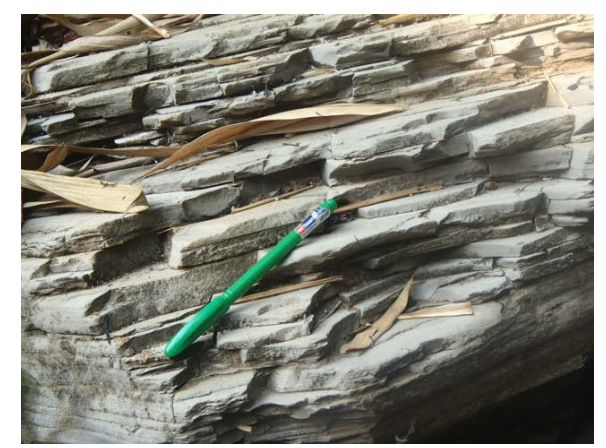

Fig. 2. (a), (b) Dark grey Lokpanta oil shale outcrops with laminated beddings.

Akande et al. [7] also reported a thermal maturity range of $424-430{ }^{\circ} \mathrm{C}$ and vitrinite reflectance of $0.43-0.55 \%$, indicating that oil shale is immature. The thickness of OS is up to $40 \mathrm{~m}$, as seen from one drill core. The oil shale reserves have been estimated at 5.76 billion tons and recoverable hydrocarbon reserves at 1.7 billion barrels [6]. Pyrolysis showed OS oil yield to be higher than 56 liters/ton [6].

The occurrence of the deposit at a shallow depth, with laterite as top soil makes it more economical to exploit. Although being probably the best method, open-pit mining may pose serious environmental and economic problems due to the loss of agricultural soil. There may also take place a release of potentially hazardous gases like $\mathrm{NO}_{2}$ and $\mathrm{SO}_{2}$, and some trace elements, although their concentrations are believed to remain relatively low [6].

The geochemical signature of oil shale is a reflection of several factors, including depositional environmental conditions [5]. Favorable conditions could result in a high concentration of valuable metals which can increase the commercial value of the oil shale. Data from previous studies suggests that the enrichment trends for major and trace elements in the Lokpanta oil shale are similar to those of the graptolite argillite of Estonia (GA), although in most cases the values are higher in the latter $[5,8,9]$.

This paper focuses on the major and trace element geochemistry of the Lokpanta oil shale and its depositional environment assessment. The geochemical depositional environment of the oil shale has been compared with that of the Estonian graptolite argillite using data from [9].

\section{Geologic setting}

The Benue Trough is one of the seven sedimentary basins in Nigeria. It is believed to have formed from the failed arm of an aulacogen which developed as a result of the separation of the African and South American plates during the Early Cretaceous [10]. It is a northeast-southwest trending basin, 
bounded on both sides by Proterozoic granites and gneisses which make up the crystalline basement $[11,12]$. The Benue Trough has a width of about $130-150 \mathrm{~km}$ and a length of up to $800 \mathrm{~km}$, extending into the Chad Basin in the northeastern direction (Fig. 1a). It is subdivided into three structural regions: the Upper Benue Trough in the north, the Lower Benue Trough in the south and the Middle Benue Trough in between. This subdivision is based on the tectonic evolution and sedimentation features, which were not uniform during the Cretaceous. Compared with the southward-lying Niger Delta Basin, relatively little is known about the Benue Trough. The southern part of the trough (the Lower Benue) experienced four depositional cycles, each being associated with transgression and regression of the sea, which led to the deposition of sedimentary units (Fig. 1a) [13-16]. The Asu River Group is the oldest of the infills of deep Cretaceous sediments in the Lower Benue Trough. It was deposited in the Albian and consists of shales and siltstones. The group has a thickness of about $2000 \mathrm{~m}$ [17]. Unconformably overlying the Asu River Group, the approximately 1000 m thick Eze-Aku Formation consists of calcareous shales, siltstones, limestone, marl and sandstone [14]. The formation houses the Lokpanta oil shale deposit. According to Ehinola [4], the Eze-Aku Formation is Late Cenomanian to Early Turonian in age. The next sediment deposition in the Lower Benue Trough corresponds to the third depositional circle which occurred during the Late Turonian to the Coniacian time. This led to the deposition of the Awgu Formation which is made up of grey bluish shales, limestones and sandstones [18]. The fourth depositional cycle saw the deposition of the Campanian marine Nkporo Shale, the Mamu Formation (lower coal measures), the Ajali Sandstone and the Nsukka Formation (upper coal measures) [13].

\section{Methods and material}

Eighteen oil shale drill core samples from three drill holes (drill hole \#1 in Lokpanta, drill hole \#2 in Acha and drill hole \#3 in Onoli-Awgu) and seven samples from outcrops were selected to be analysed in this study (Fig. 1b). The depths of the drill holes were 25.5, 40 and $36 \mathrm{~m}$, respectively. Drill cores were sampled with a step of one meter. The oil shale outcrops in the field were few and usually low-lying. The shale/marl units were fissile, laterally extensive and easily identifiable by the presence of characteristic pyrite noodles and inoceramus fossils.

Fresh outcrop samples (LK-series) were collected from seven locations within the Lokpanta deposit area. The average distance between the locations was approximately $1000 \mathrm{~m}$. The drill cores were sampled to represent the top, middle and lower parts of each drill hole. The samples were sealed in plastic sample bags and taken to the Department of Geology, University of Tartu, Estonia for analysis. 
Twenty-five selected samples were analysed for major elements by the $\mathrm{X}$-Ray Fluorescence (XRF) analyser and twelve samples were selected for analysis of trace elements, including rare earth elements (REEs), by inductively coupled plasma-mass spectrometry (ICP-MS) Two samples (CH2-7.5 and CH3-28.3) were analysed for mineral composition by the X-Ray Diffraction (XRD) method.

The dried samples were crushed and pulverized using Fritsch Pulverisette 6 with steel balls. The powdered samples were further dried at $105^{\circ} \mathrm{C}$ in Sanyo Convection OvenMOV-112F. Loss on ignition (LOI) was measured at $950{ }^{\circ} \mathrm{C}$ in Nabertherm Oven overnight to remove organic carbon and carbonate.

Samples for XRF analysis were pressed into $32 \mathrm{~mm}$ pellets by using the Herzog Press at $100 \mathrm{KN}$, while samples for XRD were pelleted by hand. The samples were studied by XRD using the Bruker D8 Advance diffractometer with $\mathrm{Ni}$ filtered $\mathrm{CuK \alpha}$ radiation, $0.3^{\circ}$ divergence slit, two $2.5^{\circ}$ Soller slits and the LynxEye line detector. Scanning steps of $0.018^{\circ} 2 \theta$ from 3 to $60^{\circ} 2 \theta$ and a total counting time of $164 \mathrm{~s}$ per step were used.

The chemical composition of samples was analysed by the Rigaku wavelength dispersive X-ray fluorescence spectrometer ZSX Primus II. $3 \mathrm{kWRh}$ primary radiation was used to measure the concentrations of elements. For calculations, the semi-quantitative SQX Analysis software was used.

For trace element concentration measurements, the samples were dissolved in the Anton Paar Multiwave PRO microwave digestion system using NXF100 digestion vessels (PTFE-TFM liner) in $8 \mathrm{~N}$ rotor, prior to analysis. $200 \mathrm{mg}$ of each sample was weighed into PTFE vessels and dissolved using a mixture of $3 \mathrm{ml}$ of $69 \% \mathrm{HNO}_{3}, 1 \mathrm{ml}$ of $35 \% \mathrm{HCl}$ and $3 \mathrm{ml}$ of $40 \% \mathrm{HF}$. After initial digestion, $18 \mathrm{ml}$ of saturated $\mathrm{H}_{3} \mathrm{BO}_{4}$ was added to the digestate and a completion run was performed. The digestates were diluted in $2 \% \mathrm{HNO}_{3}$ to a final dilution factor of 4000 and analysed using the Agilent 8800 ICP-MS calibrated with matrix matched standards. SGR-1b was used as a quality control material for digestion. ${ }^{115} \mathrm{In}$ was used as an internal standard element and NIST-1643f (trace element in natural water), diluted 10 times in

Table 1. Mineralogical composition of the Lokpanta oil shale as analysed by $\mathrm{X}$-ray diffractometry, wt\%

\begin{tabular}{|c|c|c|c|c|c|c|c|}
\hline $\begin{array}{c}\text { Sample } \\
\text { No }\end{array}$ & Location & Northings & Eastings & Quartz & $\begin{array}{c}\text { K- } \\
\text { feldspar }\end{array}$ & $\begin{array}{c}\text { Plagio- } \\
\text { clase }\end{array}$ & $\begin{array}{c}\text { Illite/ } \\
\text { smectite }\end{array}$ \\
\hline CH2-7.5 & Acha & $\begin{array}{c}5^{\circ} 50^{\prime} \\
38.3^{\prime \prime} \mathrm{N}\end{array}$ & $\begin{array}{c}7^{\circ} 29^{\prime} 8.7^{\prime \prime} \\
\mathrm{E}\end{array}$ & 15.0 & 1.5 & 3.9 & 16.0 \\
$\mathrm{CH} 3-28.3$ & $\begin{array}{c}\text { Onoli- } \\
\text { Awgu }\end{array}$ & $\begin{array}{c}6^{\circ} 1^{\prime} 21.6^{\prime \prime} \\
\mathrm{N}\end{array}$ & $\begin{array}{c}7^{\circ} 26^{\prime} \\
46.3^{\prime \prime} \mathrm{E}\end{array}$ & 21.1 & 2.0 & 1.2 & 7.4 \\
\hline
\end{tabular}


the sample matrix, as quality control during analysis. Be, $\mathrm{Mn}, \mathrm{Ga}, \mathrm{Ge}, \mathrm{Rb}, \mathrm{Sr}$, Y, Zr, Nb, Mo, Pd, Ag, Cd, Sn, Sb, Cs, Ba, REEs, Hf, Ta, W, Pt, Tl, Pb, Bi, $\mathrm{Th}$ and $\mathrm{U}$ were quantified in no-gas mode. Sc, Ti, V, Cr, Fe, Co, Ni, Cu and Zn were quantified using $6 \mathrm{ml} / \mathrm{min} \mathrm{He}$, and As and Se were quantified using $0.6 \mathrm{ml} / \mathrm{min} \mathrm{H}_{2}$ in the collision/reaction cell to eliminate polyatomic interferences.

\section{Mineralogy of the Lokpanta oil shale}

The main mineral phases were identified in two oil shale samples (Table 1). The samples contained carbonates, quartz, clay minerals, sulfides and feldspars, as well as a trace amount of anatase (Table 1). These results were in agreement with an earlier study by Sonibare et al. [8]. The clay minerals were represented by illite, kaolinite and halloysite, with illite contributing 7.4 and $16 \mathrm{wt} \%$, halloysite 5.7 and $6 \mathrm{wt} \%$ and kaolinite 9.2 and $12.7 \mathrm{wt} \%$, respectively.

Illite was most likely present as a mixture of the illite/smectite phase, which may explain the swelling behavior of oil shale when in contact with water. The difference in kaolinite concentration between the two samples could be due to the difference in burial temperature, the latter being a function of depth. The formation of kaolinite is favored at lower temperatures [19]. This could be the reason why the sample from drill core $\mathrm{CH} 2$ (taken at $7.5 \mathrm{~m}$ ) had a higher kaolinite concentration than that from drill core $\mathrm{CH} 3$ (taken at $28.3 \mathrm{~m}$ ).

The carbonate mineral phases in the studied samples were calcite and dolomite. The concentrations of calcite in drill cores $\mathrm{CH} 2$ and $\mathrm{CH} 3$ were 15.0 and $21.1 \mathrm{wt} \%$, respectively. The abundant calcite phase identified was consistent with the high concentration of $\mathrm{CaO}$ in the sample. Dolomite was present in the sample from drill core $\mathrm{CH} 2$ with a content of $24.4 \mathrm{wt} \%$, but was absent in the sample from drill core $\mathrm{CH} 3$.

Pyrite was present in the samples as the only sulfur/sulphade bearing primary phase mineral. This was in agreement with the field observation of pyrite nodules in oil shale. The oil shale samples also contained gypsum, which may suggest a certain degree of sample weathering.

Table 1 (continuation)

\begin{tabular}{|c|c|c|c|c|c|c|c|}
\hline Kaolinite & $\begin{array}{c}\text { Halloysite- } \\
7 \mathrm{~A}\end{array}$ & $\begin{array}{c}\text { Halloysite- } \\
10 \mathrm{~A}\end{array}$ & Dolomite & Calcite & Anatase & Pyrite & Gypsum \\
\hline 12.7 & 0.8 & 5.2 & 24.2 & 14.4 & $\operatorname{tr}$ & 0.8 & 5.2 \\
9.2 & 2.1 & 3.6 & & 49.9 & $\operatorname{tr}$ & 0.7 & 2.3 \\
\hline
\end{tabular}




\section{Geochemistry of the Lokpanta oil shale and comparison with the Estonian graptolite argillite}

\subsection{General geology of the Estonian graptolite argillite}

The organic-rich metalliferous black shale of Estonia - graptolite argillite can be compared with the Lokpanta oil shale since there are certain geological similarities between these rocks. The Early Ordovician GA underlies the greater part of North Estonia (see [20] for figure). It is a fine-grained, unmetamorphosed, (sub-)horizontally lying and undisturbed organic-rich $(8-20 \%)$ lithified clay, which is commonly 0.5 to $6 \mathrm{~m}$ thick and belongs to the group of black shales of sapropelic origin [9, 20-23]. The graptolite argillite crops out in some places in North Estonia, in the klint area or in some narrow river valleys. Since the entire Estonian Lower Palaeozoic sedimentary section is inclined towards the south due to its geological position in the southern slope of the Fennoscandian Shield [24], at the southwest end, the GA deposit lies at a depth greater than $250 \mathrm{~m}$.

The mineral composition of GA is dominated by K-feldspar, quartz and clay minerals. In the lateral as well as vertical dimension, the contents of the major rock-forming minerals show slight, but pronounced variation patterns $[9,22,23]$. It seems that a higher degree of sulphide mineralization within GA is associated with the occurrence of silt interbeds. Those interbeds may also contain considerable amounts of other minor authigenic compounds typical of GA - phosphates (mainly apatite as biogenic detritus and nodules), carbonates (calcite and dolomite as cement and concretions), barite and glauconite.

The Estonian GA is characterized by high to very high concentrations of $\mathrm{V}$ (1600 ppm), U (up to $1200 \mathrm{ppm}$ ), Mo (1000 ppm), Ni and other heavy metals, and is also rich in $\mathrm{N}, \mathrm{S}$ and $\mathrm{O}[9,25]$. This is quite different from the Lokpanta OS. In GA, the concentration of $\mathrm{S}$ varies between 2 and $6 \%$, of which $0.6-0.8 \%$ is comprised of organic matter, ca $0.3 \%$ is sulphatic and the remaining part is sulphitic $\mathrm{S}$ [26]. The pyrite content is also highly variable, ranging from 1.5 to $9.0 \%$, but remains mainly between 2.4 and $6 \%$. Pyrite forms fine-crystalline disseminations, thin interlayers and concretions of different forms and sizes. The diameter of the concretions is usually $2-3 \mathrm{~cm}$. Some concretions are complex in structure and contain crystals of galenite, sphalerite and calcite.

Organic matter, constituting about 15 to $20 \mathrm{wt} \%$ of GA, is sapropelic in origin [25]. The $\mathrm{C} / \mathrm{H}$ ratio in $\mathrm{OM}$ is about 9 . Although surpassing the reserves of kukersite - the Estonian oil shale, those of GA are of poor quality and unfit for production of energy. The GA calorific value ranges from 4.2 to 6.7 $\mathrm{MJ} / \mathrm{kg}$ [25] and the Fischer Assay oil yield is 3-5\% (for Estonian kukersite the latter figure is about $30-47 \%$, for example) [27]. The moisture content of fresh GA samples is from 11.9 to $12.5 \%$, while the average composition of the combustible part is: C $67.6 \%, \mathrm{O} 18.5 \%, \mathrm{H} 7.6 \%, \mathrm{~N} \mathrm{3.6 \%}$ and S 2.6\% [28]. 
The high concentrations of some elements in GA may, on the one hand, be useful, but on the other, hazardous [29]. During the Soviet era, GA was mined for uranium production at Sillamäe, Northeast Estonia between 1948 and 1952 [27]. A total of 22.5 tons of elemental uranium was produced from 272,000 tons of GA from an underground mine. The Estonian GA can be considered as a low-grade oil source, with its potential oil reserves of about 2.1 billion tonnes [27]. Considering this, the Swedish Alum Shale together with Estonian GA were thought to be a potential source of energy in the future. Based on certain similarities, it would be interesting to compare the geochemical features and paleo-environmental conditions of the Lokpanta OS and the Estonian GA.

\subsection{Major compounds in the Lokpanta oil shale}

The results of chemical analysis of the major compounds contained in the Lokpanta oil shale are presented in Table 2. There may be observed little variation in geochemistry among these compounds. The $\mathrm{SiO}_{2}$ content ranges from 22.59 to $54.95 \mathrm{wt} \%$ with an average value of $35.14 \mathrm{wt} \%$. The amount of $\mathrm{CaO}$ in the study area is $11-32.83 \mathrm{wt} \%$ with only one sample showing a lower value $(2.16 \mathrm{wt} \%)$. The $\mathrm{Al}_{2} \mathrm{O}_{3}$ content is the highest in $\mathrm{CH} 2$, varying between 6.3 and 15.99 wt $\%$ in all samples. Loss on ignition (LOI@950) against CaO indicates a good positive correlation $\left(\mathrm{R}^{2}=0.90\right.$; Table 3$)$, while the correlation of $\mathrm{CaO}$ with $\mathrm{SiO}_{2}$ is negative. The positive correlation between $\mathrm{TiO}_{2}$ and $\mathrm{Al}_{2} \mathrm{O}_{3}$ suggests the detrital origin of $\mathrm{Ti}$. $\mathrm{TiO}_{2}$ also has a positive correlation with $\mathrm{SiO}_{2}$. The $\mathrm{Fe}_{2} \mathrm{O}_{3}$ content ranges from 2.3 to $7.3 \mathrm{wt} \%$ and the compound mostly shows scattering. $\mathrm{Na}_{2} \mathrm{O}$ and $\mathrm{K}_{2} \mathrm{O}$ are similarly scattered, their concentrations being commonly low, up to 0.9 and $1.8 \mathrm{wt} \%$, respectively. The concentration of $\mathrm{P}_{2} \mathrm{O}_{5}$ is usually very low, $0.06-0.18 \mathrm{wt} \%$.

The Lokpanta OS is highly enriched in $\mathrm{CaO}$ and $\mathrm{Na}_{2} \mathrm{O}$ when compared with the Estonian GA (Fig. 3). There is a high enrichment of $\mathrm{CaO}$ in drill core $\mathrm{CH} 1$ but depletion in $\mathrm{SiO}_{2}$, while the case is vice versa with other drill cores. $\mathrm{CaO}$ shows a negative correlation with $\mathrm{Al}_{2} \mathrm{O}_{3}$, which suggests that the former is derived from carbonates.

Geochemical values indicate that in the study area, the outcrop samples have the highest $\mathrm{SiO}_{2}$ content (Table 2). Being concentrated in the clay fraction, the $\mathrm{Al}_{2} \mathrm{O}_{3}$ content generally increases with decreasing $\mathrm{SiO}_{2}$ content. In the studied samples, $\mathrm{Al}_{2} \mathrm{O}_{3}$ shows a weak positive correlation with $\mathrm{SiO}_{2}$. Apart from samples LK-19 and LK-7, in all other samples the $\mathrm{Al}_{2} \mathrm{O}_{3}$ concentration was observed to increase with increasing $\mathrm{SiO}_{2}$ content. The positive correlation of $\mathrm{K}_{2} \mathrm{O}$ and $\mathrm{TiO}_{2}$ with $\mathrm{Al}_{2} \mathrm{O}_{3}$ shows the two former to be associated with clay minerals. When compared to the Post-Archean Australian Shale (PAAS) [30], the Lokpanta OS samples are generally depleted in major compounds except $\mathrm{CaO}$, which is enriched in all drill core and outcrop samples, $\mathrm{P}_{2} \mathrm{O}_{5}$ is abundant in $\mathrm{CH} 1, \mathrm{CH} 2$ and $\mathrm{CH} 3$ and $\mathrm{Na}_{2} \mathrm{O}$ in $\mathrm{CH} 2$ (Fig. 3). 
Table 2. Major compound concentrations in the Lokpanta oil shale, wt\%

\begin{tabular}{|c|c|c|c|c|c|c|c|}
\hline \multirow{3}{*}{$\begin{array}{c}\text { Sample } \\
\text { No }\end{array}$} & \multirow{3}{*}{$\begin{array}{l}\text { Location } \\
\text { Lokpanta }\end{array}$} & \multicolumn{2}{|c|}{ Coordinates } & \multirow{3}{*}{$\begin{array}{c}\mathrm{SiO}_{2} \\
22.59\end{array}$} & \multirow{3}{*}{$\frac{\mathrm{TiO}_{2}}{0.45}$} & \multirow{3}{*}{$\frac{\mathrm{Al}_{2} \mathrm{O}_{3}}{6.30}$} & \multirow{3}{*}{$\begin{array}{c}\mathrm{Fe}_{2} \mathrm{O}_{3} \\
2.33\end{array}$} \\
\hline & & Northings & Eastings & & & & \\
\hline & & $\begin{array}{c}5^{\circ} 59^{\prime} 39.3^{\prime \prime} \\
\mathrm{N}\end{array}$ & $\begin{array}{c}7^{\circ} 19^{\prime} \\
58.30^{\prime \prime} \mathrm{E}\end{array}$ & & & & \\
\hline CH1-2 & $"$ & & & 23.12 & 0.43 & 6.37 & 2.35 \\
\hline CH1-3 & $"$ & & & 25.87 & 0.58 & 7.72 & 2.70 \\
\hline CH1-4 & " & & & 25.27 & 0.50 & 7.44 & 2.89 \\
\hline $\mathrm{CH} 2-4.5$ & Acha & $\begin{array}{c}5^{\circ} 50^{\prime} 38.3^{\prime \prime} \\
\mathrm{N}\end{array}$ & $\begin{array}{c}7^{\circ} 29^{\prime} 8.7^{\prime \prime} \\
\mathrm{E}\end{array}$ & 41.21 & 0.85 & 15.05 & 6.21 \\
\hline $\mathrm{CH} 2-5.5$ & $"$ & & & 38.71 & 0.86 & 14.05 & 5.66 \\
\hline $\mathrm{CH} 2-7.5$ & $"$ & & & 27.71 & 0.46 & 8.81 & 7.31 \\
\hline $\mathrm{CH} 2-15.5$ & $"$ & & & 36.95 & 0.91 & 13.56 & 6.15 \\
\hline $\mathrm{CH} 2-31.5$ & $"$ & & & 36.36 & 0.49 & 9.17 & 4.98 \\
\hline $\mathrm{CH} 2-34.5$ & $"$ & & & 41.10 & 0.63 & 11.03 & 5.77 \\
\hline $\mathrm{CH} 2-37.5$ & $"$ & & & 41.87 & 0.84 & 15.99 & 5.48 \\
\hline $\mathrm{CH} 3-3.3$ & Onoli-Awgu & $\begin{array}{c}6^{\circ} 1^{\prime} 21.6^{\prime \prime} \\
\mathrm{N}\end{array}$ & $\begin{array}{c}7^{\circ} 26^{\prime} 46.3^{\prime \prime} \\
\mathrm{E}\end{array}$ & 33.76 & 0.54 & 10.27 & 4.51 \\
\hline $\mathrm{CH} 3-4.3$ & $"$ & & & 39.24 & 0.77 & 14.90 & 4.02 \\
\hline $\mathrm{CH} 3-7.3$ & $"$ & & & 38.38 & 0.69 & 12.73 & 3.94 \\
\hline CH3-15.3 & $"$ & & & 35.21 & 0.65 & 11.47 & 3.55 \\
\hline $\mathrm{CH} 3-25.3$ & $"$ & & & 35.67 & 0.61 & 12.07 & 4.43 \\
\hline CH3-26.3 & $"$ & & & 31.61 & 0.68 & 11.15 & 4.39 \\
\hline CH3-28.3 & $"$ & & & 30.89 & 0.46 & 7.66 & 2.31 \\
\hline LK-7 & $\begin{array}{l}\text { Lokpanta } \\
\text { (outcrop) }\end{array}$ & $\begin{array}{c}5^{\circ} 58^{\prime} 39.6^{\prime \prime} \\
\mathrm{N}\end{array}$ & $\begin{array}{c}7^{\circ} 27^{\prime} 13.6^{\prime \prime} \\
\mathrm{E}\end{array}$ & 38.74 & 0.37 & 7.50 & 3.48 \\
\hline LK-8 & " & $\begin{array}{c}5^{\circ} 58^{\prime} 39.6^{\prime \prime} \\
\mathrm{N}\end{array}$ & $\begin{array}{c}7^{\circ} 27^{\prime} 38.6^{\prime \prime} \\
\mathrm{E}\end{array}$ & 40.59 & 0.38 & 7.65 & 3.61 \\
\hline LK-15 & $"$ & $\begin{array}{c}5^{\circ} 58^{\prime} 44.6^{\prime \prime} \\
\mathrm{N}\end{array}$ & $\begin{array}{c}7^{\circ} 27^{\prime} 53.1^{\prime \prime} \\
\mathrm{E}\end{array}$ & 36.57 & 0.51 & 8.68 & 4.09 \\
\hline LK-19 & $"$ & $\begin{array}{c}5^{\circ} 59^{\prime} 51.1^{\prime \prime} \\
\mathrm{N}\end{array}$ & $\begin{array}{c}7^{\circ} 27^{\prime} 31.5^{\prime \prime} \\
\mathrm{E}\end{array}$ & 54.95 & 0.53 & 9.24 & 2.60 \\
\hline LK-25 & " & $\begin{array}{c}6^{\circ} 0^{\prime} 20.1^{\prime \prime} \\
\mathrm{N}\end{array}$ & $\begin{array}{c}7^{\circ} 27^{\prime} 31.1^{\prime \prime} \\
\mathrm{E}\end{array}$ & 34.81 & 0.52 & 12.28 & 5.39 \\
\hline LK-28 & $"$ & $\begin{array}{c}6^{\circ} 0^{\prime} 20.1^{\prime \prime} \\
\mathrm{N}\end{array}$ & $\begin{array}{c}7^{\circ} 27^{\prime} 42.1^{\prime \prime} \\
\mathrm{E}\end{array}$ & 35.49 & 0.59 & 13.90 & 6.24 \\
\hline LK-30 & $"$ & $\begin{array}{c}5^{\circ} 58^{\prime} 39.5^{\prime \prime} \\
\mathrm{N}\end{array}$ & $\begin{array}{c}7^{\circ} 27^{\prime} 38.6^{\prime \prime} \\
\mathrm{E}\end{array}$ & 31.80 & 0.55 & 10.62 & 3.30 \\
\hline
\end{tabular}


Table 2 (continuation)

\begin{tabular}{|c|c|c|c|c|c|c|c|}
\hline $\mathrm{MgO}$ & $\mathrm{CaO}$ & $\mathrm{Na}_{2} \mathrm{O}$ & $\mathrm{K}_{2} \mathrm{O}$ & $\mathrm{P}_{2} \mathrm{O}_{5}$ & $\mathrm{SO}_{3}$ & $\begin{array}{c}\text { LOI@950C, } \\
\text { wt } \%\end{array}$ & Sum \\
\hline 0.71 & 32.83 & 0.27 & 0.72 & 0.30 & 1.23 & 31.98 & 99.71 \\
\hline 0.68 & 32.71 & 0.36 & 0.74 & 0.18 & 1.25 & 31.55 & 99.74 \\
\hline 0.83 & 29.39 & 0.34 & 0.93 & 0.22 & 1.42 & 29.72 & 99.73 \\
\hline 0.82 & 28.99 & 0.39 & 0.88 & 0.17 & 2.54 & 29.87 & 99.76 \\
\hline 1.23 & 11.97 & 0.93 & 1.41 & 0.12 & 5.28 & 15.53 & 99.79 \\
\hline 1.31 & 14.63 & 0.92 & 1.66 & 0.18 & 4.10 & 17.69 & 99.77 \\
\hline 2.56 & 19.47 & 0.77 & 0.86 & 0.17 & 3.97 & 27.67 & 99.76 \\
\hline 0.28 & 2.17 & 9.04 & 0.43 & 0.34 & 12.61 & 17.39 & 99.83 \\
\hline 1.09 & 17.68 & 0.66 & 1.10 & 0.13 & 5.25 & 22.89 & 99.79 \\
\hline 0.91 & 10.98 & 0.77 & 1.31 & 0.16 & 8.66 & 18.46 & 99.78 \\
\hline 1.11 & 10.56 & 0.66 & 1.78 & 0.15 & 5.34 & 15.97 & 99.75 \\
\hline 1.14 & 20.98 & 0.37 & 1.36 & 0.07 & 2.63 & 24.12 & 99.74 \\
\hline 1.13 & 14.14 & 0.34 & 1.79 & 0.06 & 2.14 & 21.07 & 99.59 \\
\hline 1.10 & 16.81 & 0.37 & 1.46 & 0.04 & 2.41 & 21.86 & 99.79 \\
\hline 1.14 & 20.01 & 0.80 & 1.53 & 0.87 & 1.95 & 22.53 & 99.70 \\
\hline 1.22 & 18.97 & 0.82 & 1.36 & 0.14 & 2.87 & 21.62 & 99.78 \\
\hline 1.11 & 21.36 & 0.73 & 1.31 & 0.20 & 3.85 & 23.39 & 99.79 \\
\hline 0.90 & 26.44 & 0.48 & 0.87 & 0.10 & 2.25 & 27.33 & 99.68 \\
\hline 0.98 & 23.74 & 0.40 & 0.58 & 0.18 & 0.67 & 23.18 & 99.82 \\
\hline 0.89 & 21.59 & 0.32 & 0.58 & 0.14 & 0.65 & 23.41 & 99.80 \\
\hline 0.58 & 22.02 & 0.24 & 0.68 & 0.13 & 0.40 & 25.92 & 99.83 \\
\hline 0.71 & 13.21 & 0.29 & 0.99 & 0.10 & 1.40 & 15.78 & 99.81 \\
\hline 1.26 & 17.96 & 0.75 & 1.11 & 0.19 & 1.97 & 23.52 & 99.76 \\
\hline 1.17 & 16.57 & 0.59 & 1.15 & 0.20 & 1.96 & 21.9 & 99.75 \\
\hline 1.02 & 21.48 & 0.56 & 1.33 & 0.08 & 1.04 & 27.9 & 99.67 \\
\hline
\end{tabular}




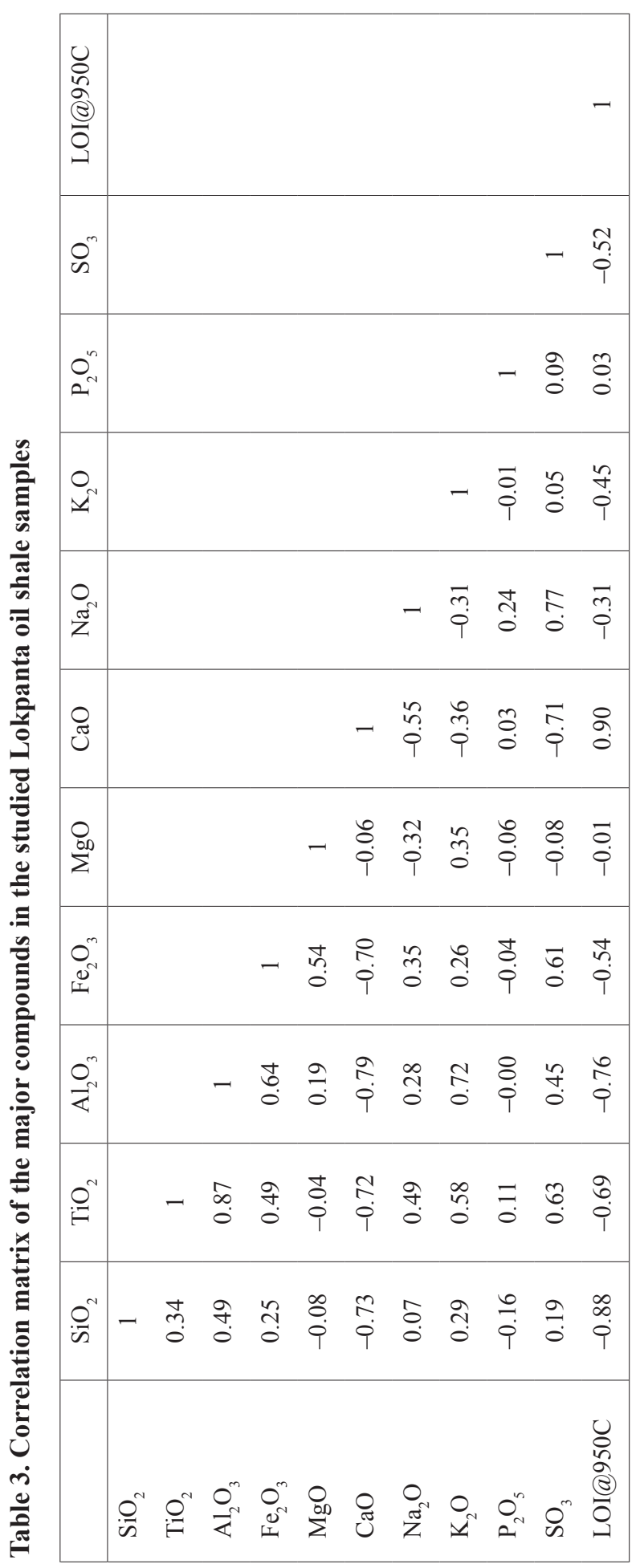




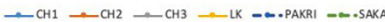

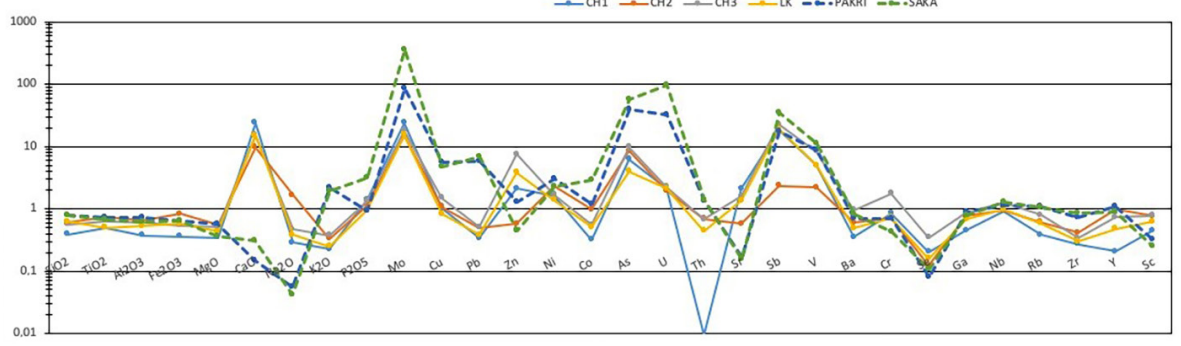

Fig. 3. PAAS normalized concentrations of major and trace elements and compounds of the Lokpanta oil shale and the Estonian graptolite argillite (grouped values from [20]). Values for PAAS after [30]. $\mathrm{CH} 1, \mathrm{CH} 2$ and $\mathrm{CH} 3$ indicate the average concentrations of elements and compounds from drill cores $\mathrm{CH} 1, \mathrm{CH} 2$ and $\mathrm{CH} 3$, respectively; LK indicates the average concentrations from outcrop samples; PAKRI and SAKA indicate the average concentrations of elements and concentrations of the Estonian graptolite argillite samples from two outcrops in the western and eastern zones, respectively.

\subsection{Trace elements in the Lokpanta oil shale}

The concentrations of trace and rare earth elements in the studied samples are given in Tables 4 and 5, respectively. The concentrations of major and trace elements were normalized using PAAS values (Fig. 3) [30]. Trace metals, especially $\mathrm{Mo}, \mathrm{Pb}, \mathrm{Cu}, \mathrm{Co}, \mathrm{As}, \mathrm{U}$ and $\mathrm{Th}$, were commonly present in low concentrations if compared with black shales, the Estonian graptolite argillite, for example [20]. However, differently from PAAS, the Lokpanta OS shows greatly varying concentrations of Mo (4-66 ppm), Cu (15-41 ppm), Zn (19-768 ppm), As (4-29 ppm), U (3-10 ppm) and V (60-1635 ppm). Most trace metals exhibit highly scattered concentrations when plotted against $\mathrm{SiO}_{2}$. Compared to other drill cores, there is a high enrichment of $\mathrm{Sr}$ and a low enrichment of $\mathrm{Mn}$ in CH1. The high Sr concentrations (180-746 ppm) may be associated with calcite minerals. In general, the Lokpanta OS is enriched in $\mathrm{Zn}$ and $\mathrm{Sr}$ (except in $\mathrm{CH} 2$ ), Mo, $\mathrm{V}$ and $\mathrm{U}$. In addition, unlike PAAS, this oil shale is depleted in $\mathrm{Ba}$ and $\mathrm{Rb}$, which are usually concentrated in K-feldspars and phyllosilicates, with average values of 335 and 68 ppm, respectively.

The Estonian GA is highly enriched in U, Mo and As [9 ], but significantly depleted in Sr when compared with PAAS and the Lokpanta OS.

The REEs concentrations in samples from drill core $\mathrm{CH} 1$ and outcrops are shown to be much lower than PAAS normalized values (Fig. 4). The concentrations of heavy REEs in the Lokpanta OS are much lower than those in PAAS and the Estonian GA. Middle REEs seem to be slightly enriched in the Lokpanta OS, as seen from Figure 4. This is the main difference between the Lokpanta OS and the Estonian GA (Fig. 4). 
Table. 4. Trace element concentrations in the Lokpanta oil shale samples, ppm

\begin{tabular}{|c|c|c|c|c|c|c|c|c|c|c|c|c|}
\hline \multirow{3}{*}{$\begin{array}{c}\begin{array}{c}\text { Sample } \\
\text { No }\end{array} \\
\text { CH1-2 }\end{array}$} & \multirow{3}{*}{$\begin{array}{l}\text { Location } \\
\text { Lokpanta }\end{array}$} & \multirow{2}{*}{\multicolumn{2}{|c|}{\begin{tabular}{l}
\multicolumn{2}{c}{ Coordinates } \\
Northings $\quad$ Eastings
\end{tabular}}} & \multirow{3}{*}{$\begin{array}{c}\text { Mo } \\
6.56\end{array}$} & \multirow{3}{*}{$\begin{array}{c}\mathrm{Cu} \\
27.26\end{array}$} & \multirow{3}{*}{$\begin{array}{c}\mathrm{Pb} \\
6.92\end{array}$} & \multirow{3}{*}{$\begin{array}{c}\mathrm{Zn} \\
200.09\end{array}$} & \multirow{3}{*}{$\begin{array}{c}\mathrm{Ni} \\
41.70\end{array}$} & \multirow{3}{*}{\begin{tabular}{|c|} 
Co \\
4.04
\end{tabular}} & \multirow{3}{*}{$\begin{array}{l}\text { As } \\
7.83\end{array}$} & \multirow{3}{*}{$\begin{array}{c}\mathrm{U} \\
3.81\end{array}$} & \multirow{3}{*}{$\begin{array}{c}\text { Th } \\
0.07\end{array}$} \\
\hline & & & & & & & & & & & & \\
\hline & & $\begin{array}{c}5^{\circ} 59^{\prime} \\
39.3^{\prime \prime} \mathrm{N}\end{array}$ & $\begin{array}{c}7^{\circ} 19^{\prime} \\
58.30^{\prime \prime} \mathrm{E}\end{array}$ & & & & & & & & & \\
\hline CH1-4 & $"$ & & & 65.81 & 22.93 & 6.46 & 99.69 & 99.66 & 6.81 & 10.97 & 8.17 & 0.13 \\
\hline $\mathrm{CH} 2-5.5$ & Acha & $\begin{array}{c}5^{\circ} 50^{\prime} \\
38.3^{\prime \prime} \mathrm{N}\end{array}$ & $\begin{array}{l}7^{\circ} 29^{\prime} \\
8.7^{\prime \prime} \mathrm{E}\end{array}$ & 27.48 & 21.92 & 10.67 & 77.64 & 115.41 & 19.25 & 15.01 & 4.81 & 8.35 \\
\hline $\mathrm{CH} 2-7.5$ & $"$ & & & 8.33 & 19.33 & 8.53 & 18.88 & 46.76 & 12.45 & 7.96 & 5.28 & 6.25 \\
\hline CH2-34.5 & $"$ & & & 32.40 & 40.14 & 10.72 & 24.55 & 143.15 & 17.96 & 14.98 & 6.14 & 7.27 \\
\hline $\mathrm{CH} 3-4.3$ & $\begin{array}{l}\text { Onoli- } \\
\text { Awgu }\end{array}$ & $\begin{array}{c}6^{\circ} 1^{\prime} \\
21.6^{\prime \prime} \mathrm{N}\end{array}$ & $\begin{array}{l}7^{\circ} 26^{\prime} \\
46.3^{\prime \prime} \mathrm{E}\end{array}$ & 44.44 & 36.05 & 11.60 & 570.66 & 101.89 & 11.95 & 7.43 & 10.19 & 11.97 \\
\hline CH3-25.3 & $"$ & & & 4.46 & 41.07 & 11.25 & 242.24 & 53.56 & 7.89 & 7.34 & 3.00 & 9.23 \\
\hline CH3-28.3 & $"$ & & & 32.57 & 34.56 & 7.45 & 768.08 & 69.45 & 8.24 & 29.35 & 5.73 & 0.23 \\
\hline LK-8 & $\begin{array}{l}\text { Lokpanta } \\
\text { (outcrop) }\end{array}$ & $\begin{array}{c}5^{\circ} 58^{\prime} \\
39.6^{\prime \prime} \mathrm{N}\end{array}$ & $\begin{array}{l}7^{\circ} 27^{\prime} \\
38.6^{\prime \prime} \mathrm{E}\end{array}$ & 5.00 & 20.59 & 4.68 & 491.85 & 31.15 & 5.17 & 2.34 & 2.50 & 5.21 \\
\hline LK-15 & $"$ & $\begin{array}{c}5^{\circ} 58^{\prime} \\
44.6^{\prime \prime} \mathrm{N}\end{array}$ & $\begin{array}{l}7^{\circ} 27^{\prime} \\
53.1^{\prime \prime} \mathrm{E}\end{array}$ & 9.25 & 16.14 & 8.12 & 40.87 & 44.49 & 13.36 & 7.74 & 8.79 & 6.46 \\
\hline LK-19 & $"$ & $\begin{array}{c}5^{\circ} 59^{\prime} \\
51.1^{\prime \prime} \mathrm{N}\end{array}$ & $\begin{array}{l}7^{\circ} 27^{\prime} \\
31.5^{\prime \prime} \mathrm{E}\end{array}$ & 21.86 & 15.04 & 6.68 & 123.46 & 58.30 & 7.16 & 3.69 & 3.49 & 6.91 \\
\hline LK-30 & $"$ & $\begin{array}{c}5^{\circ} 58^{\prime} \\
39.5^{\prime \prime} \mathrm{N}\end{array}$ & $\begin{array}{c}7^{\circ} 27^{\prime} \\
38.6^{\prime \prime} \mathrm{E}\end{array}$ & 56.03 & 30.95 & 10.72 & 420.97 & 108.28 & 8.61 & 9.94 & 9.10 & 0.26 \\
\hline
\end{tabular}

Table 5. Rare earth element concentrations in the Lokpanta oil shale samples

\begin{tabular}{|c|c|c|c|c|c|c|c|c|}
\hline \multirow{3}{*}{$\begin{array}{c}\begin{array}{c}\text { Sample } \\
\text { No }\end{array} \\
\text { CH1-2 }\end{array}$} & \multirow{2}{*}{ Location } & \multicolumn{2}{|c|}{ Coordinates } & \multirow{2}{*}{$\mathrm{La}$} & \multirow{2}{*}{$\mathrm{Ce}$} & \multirow{2}{*}{$\operatorname{Pr}$} & \multirow{2}{*}{$\mathrm{Nd}$} & \multirow{2}{*}{ Sm } \\
\hline & & Northings & Eastings & & & & & \\
\hline & $\begin{array}{l}\text { Lokpanta } \\
\text { (drill hole 1) }\end{array}$ & $5^{\circ} 59^{\prime} 39.3^{\prime \prime} \mathrm{N}$ & $7^{\circ} 19^{\prime} 58.30^{\prime \prime} \mathrm{E}$ & 9.79 & 20.53 & 2.33 & 8.96 & 1.62 \\
\hline CH1-4 & " & & & 14.70 & 32.94 & 3.61 & 13.90 & 2.57 \\
\hline $\mathrm{CH} 2-5.5$ & $\begin{array}{c}\text { Acha } \\
\text { (drill hole 2) }\end{array}$ & $5^{\circ} 50^{\prime} 38.3^{\prime \prime} \mathrm{N}$ & $7^{\circ} 29^{\prime} 8.7^{\prime \prime} \mathrm{E}$ & 41.97 & 84.03 & 9.90 & 37.95 & 7.23 \\
\hline $\mathrm{CH} 2-7.5$ & $"$ & & & 29.36 & 56.14 & 6.27 & 23.44 & 4.24 \\
\hline $\mathrm{CH} 2-34.5$ & $"$ & & & 34.89 & 67.49 & 7.79 & 29.52 & 5.49 \\
\hline CH3-4.3 & $\begin{array}{l}\text { Onoli-Awgu } \\
\text { (drill hole 3) }\end{array}$ & $6^{\circ} 1^{\prime} 21.6^{\prime \prime} \mathrm{N}$ & $7^{\circ} 26^{\prime} 46.3^{\prime \prime} \mathrm{E}$ & 40.35 & 68.13 & 7.14 & 23.71 & 3.86 \\
\hline CH3-25.3 & $"$ & & & 61.13 & 125.06 & 15.40 & 57.70 & 10.44 \\
\hline CH3-28.3 & " & & & 16.30 & 40.40 & 3.96 & 15.07 & 2.75 \\
\hline LK-8 & $\begin{array}{l}\text { Lokpanta } \\
\text { (outcrops) }\end{array}$ & $5^{\circ} 58^{\prime} 39.6^{\prime \prime} \mathrm{N}$ & $7^{\circ} 27^{\prime} 38.6^{\prime \prime} \mathrm{E}$ & 23.98 & 48.99 & 5.21 & 19.26 & 3.46 \\
\hline LK-15 & $"$ & $5^{\circ} 58^{\prime} 44.6^{\prime \prime} \mathrm{N}$ & $7^{\circ} 27^{\prime} 53.1^{\prime \prime} \mathrm{E}$ & 26.43 & 49.56 & 5.58 & 20.50 & 3.71 \\
\hline LK-19 & $"$ & $5^{\circ} 59^{\prime} 51.1^{\prime \prime} \mathrm{N}$ & $7^{\circ} 27^{\prime} 31.5^{\prime \prime} \mathrm{E}$ & 28.81 & 50.14 & 5.38 & 19.28 & 3.39 \\
\hline LK-30 & $"$ & $5^{\circ} 58^{\prime} 39.5^{\prime \prime} \mathrm{N}$ & $7^{\circ} 27^{\prime} 38.6^{\prime \prime} \mathrm{E}$ & 16.73 & 47.14 & 4.41 & 16.55 & 2.94 \\
\hline
\end{tabular}


Table 4 (continuation)

\begin{tabular}{|c|c|c|c|c|c|c|c|c|c|c|c|c|c|}
\hline $\mathrm{Sr}$ & $\mathrm{Sb}$ & V & $\mathrm{Ba}$ & $\mathrm{Cr}$ & $\mathrm{Se}$ & $\mathrm{Ga}$ & $\mathrm{Nb}$ & $\mathrm{Rb}$ & $\mathrm{Zr}$ & Y & $\mathrm{Sc}$ & $\mathrm{Be}$ & $\mathrm{Mn}$ \\
\hline 734.76 & 2.60 & 457.13 & 145.13 & 87.90 & 11.64 & 6.37 & 9.46 & 36.29 & 38.37 & 3.35 & 4.90 & 0.90 & 113.06 \\
\hline 746.03 & 4.75 & 605.30 & 240.85 & 52.78 & 8.61 & 8.91 & 12.66 & 48.42 & 63.15 & 5.68 & 7.19 & 1.17 & 138.45 \\
\hline 217.30 & 0.66 & 369.85 & 234.67 & 60.81 & 9.30 & 14.18 & 14.58 & 83.37 & 104.85 & 24.38 & 11.15 & 1.99 & 264.41 \\
\hline 206.53 & 0.17 & 66.62 & 371.97 & 49.04 & 2.72 & 11.80 & 10.28 & 59.48 & 70.26 & 17.25 & 9.27 & 1.93 & 1072.22 \\
\hline 179.02 & 0.58 & 272.67 & 378.22 & 67.37 & 6.35 & 12.78 & 9.65 & 61.51 & 60.96 & 23.42 & 10.79 & 1.50 & 282.44 \\
\hline 423.26 & 5.79 & 1634.75 & 414.30 & 120.48 & 17.79 & 18.19 & 17.38 & 119.00 & 65.82 & 11.46 & 13.62 & 2.27 & 190.58 \\
\hline 509.45 & 3.66 & 180.31 & 703.30 & 229.31 & 14.75 & 15.30 & 15.34 & 90.30 & 68.47 & 30.72 & 10.26 & 2.06 & 149.29 \\
\hline 737.30 & 4.13 & 859.88 & 453.23 & 87.99 & 19.17 & 10.14 & 12.16 & 56.17 & 55.88 & 6.22 & 7.56 & 1.38 & 132.30 \\
\hline 381.83 & 5.96 & 435.37 & 186.77 & 56.70 & 12.12 & 9.24 & 7.87 & 46.82 & 47.13 & 12.39 & 7.36 & 2.25 & 248.12 \\
\hline 679.82 & 2.61 & 67.52 & 428.20 & 45.34 & 5.40 & 11.20 & 10.90 & 54.77 & 63.37 & 12.85 & 9.14 & 1.64 & 418.02 \\
\hline 323.24 & 1.18 & 409.94 & 168.68 & 58.56 & 2.75 & 11.23 & 13.40 & 63.82 & 58.67 & 11.84 & 7.54 & 1.18 & 224.95 \\
\hline 484.27 & 5.45 & 1225.78 & 290.60 & 78.25 & 11.38 & 14.54 & 14.28 & 94.02 & 57.28 & 5.03 & 9.99 & 2.05 & 146.12 \\
\hline
\end{tabular}

Table 5 (continuation)

\begin{tabular}{|c|c|c|c|c|c|c|c|c|}
\hline $\mathrm{Eu}$ & $\mathrm{Gd}$ & $\mathrm{Tb}$ & Dy & Но & $\mathrm{Er}$ & $\mathrm{Tm}$ & $\mathrm{Yb}$ & $\mathrm{Lu}$ \\
\hline 0.37 & 1.47 & 0.20 & 1.08 & 0.21 & 0.61 & 0.08 & 0.49 & 0.07 \\
\hline 0.60 & 2.29 & 0.31 & 1.63 & 0.32 & 0.89 & 0.11 & 0.75 & 0.10 \\
\hline 1.58 & 6.45 & 0.86 & 4.36 & 0.80 & 2.18 & 0.28 & 1.74 & 0.24 \\
\hline 0.98 & 3.91 & 0.53 & 2.77 & 0.53 & 1.46 & 0.19 & 1.20 & 0.16 \\
\hline 1.25 & 5.12 & 0.69 & 3.66 & 0.71 & 1.97 & 0.26 & 1.65 & 0.23 \\
\hline 0.74 & 3.25 & 0.43 & 2.28 & 0.44 & 1.29 & 0.19 & 1.30 & 0.18 \\
\hline 2.08 & 8.77 & 1.09 & 5.23 & 0.93 & 2.42 & 0.28 & 1.68 & 0.23 \\
\hline 0.65 & 2.49 & 0.33 & 1.71 & 0.33 & 0.93 & 0.12 & 0.76 & 0.11 \\
\hline 0.71 & 3.11 & 0.40 & 2.03 & 0.39 & 1.10 & 0.14 & 0.92 & 0.13 \\
\hline 0.83 & 3.31 & 0.44 & 2.26 & 0.43 & 1.18 & 0.16 & 1.01 & 0.14 \\
\hline 0.70 & 2.93 & 0.39 & 1.97 & 0.38 & 1.06 & 0.14 & 0.91 & 0.13 \\
\hline 0.58 & 2.43 & 0.32 & 1.66 & 0.32 & 0.90 & 0.12 & 0.75 & 0.11 \\
\hline
\end{tabular}




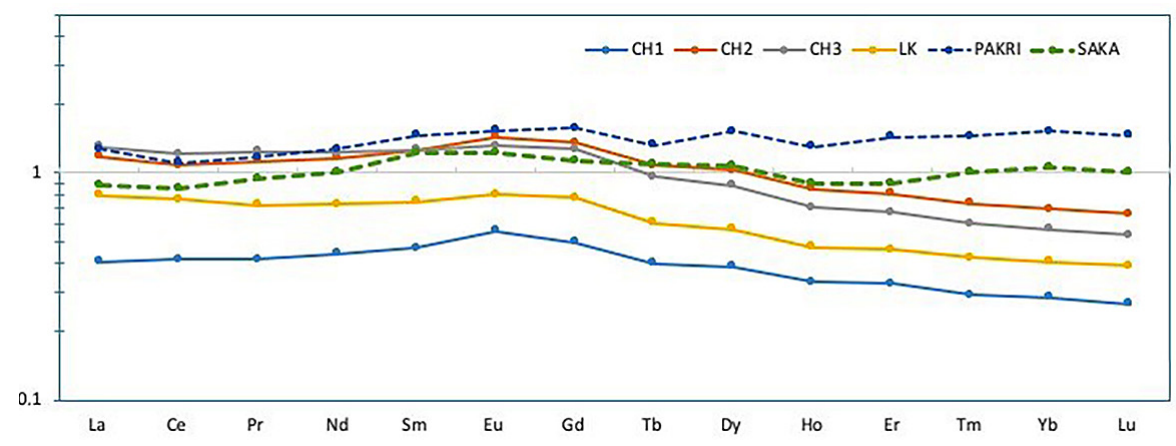

Fig. 4. PAAS normalized concentrations of REEs plot for the Lokpanta oil shale and the Estonian graptolite argillite samples. Values for PAAS after [30]. $\mathrm{CH} 1, \mathrm{CH} 2$ and $\mathrm{CH} 3$ indicate the average concentrations of elements from drill cores $\mathrm{CH} 1, \mathrm{CH} 2$ and $\mathrm{CH} 3$, respectively; LK indicates the average REEs concentrations from outcrop samples; PAKRI and SAKA indicate the average REEs concentrations of the Estonian graptolite argillite samples from two outcrops in the western and eastern zones, respectively.

\section{Discussion}

Earlier the Lokpanta oil shale was believed to be a facies of the Eze-Aku Formation. But a new line of thought is that it is very distinct from said formation and should be promoted to the status of a Formation, hence "the Lokpanta Formation" is used in this publication. This proposal was made in October 2017 at a meeting organized by the National Association of Petroleum Explorationists in Portharcourt, Nigeria. The proposal was corroborated by geochemical and paleontological data. The Lokpanta oil shale is bituminous and has a significantly higher total organic carbon than the Eze-Aku Formation. The presence of inoceramus moulds, poorly developed ammonites and the isotopic signature demonstrate that the Lokpanta oil shale was deposited during the global oxygen minimum event [31].

\subsection{Tectonic settings and depositional environment}

Clastic rocks from different tectonic settings possess specific chemistry. Roser and Korsch [32] have established a classification of tectonic settings into passive margin, active continental margin and oceanic island arc groups based on $\mathrm{SiO}_{2}$ content and $\mathrm{K}_{2} \mathrm{O} / \mathrm{Na}_{2} \mathrm{O}$ ratio. Sediments of the passive margin setting are quartz-rich, but depleted in $\mathrm{CaO}$ and $\mathrm{Na}_{2} \mathrm{O}$, and were deposited in plate interiors at stable continental margins. The active margin sediments are mineralogically less mature than the passive margin sediments. On the other hand, oceanic island arc sediments are mineralogically immature and are derived from oceanic island arcs [32]. The Lokpanta oil shale plots within 
the active continental margin field in the $\mathrm{SiO}_{2} \mathrm{vs} \mathrm{K}_{2} \mathrm{O} / \mathrm{Na}_{2} \mathrm{O}$ diagram, which suggests deposition in an active continental margin(Fig. 5a). This interpretation agrees with that of Adeigbe and Jimoh [33]. The Estonian GA has generally the $\mathrm{SiO}_{2}$ content between 45 and $52 \mathrm{wt} \%$ and the $\mathrm{K}_{2} \mathrm{O} / \mathrm{Na}_{2} \mathrm{O}$ ratio above 100 , 110-146. So, it plots slightly outside the presented fields, but in the passive margin field (Fig. 5a). The reason for the GA's high K content and the very low $\mathrm{Na}$ concentration, which account for the high $\mathrm{K}_{2} \mathrm{O} / \mathrm{Na}_{2} \mathrm{O}$ ratios, needs still to be elucidated. The enrichment of $\mathrm{CaO}$ (average concentration $19.5 \mathrm{wt} \%$ ) and a certain depletion in $\mathrm{SiO}_{2}$ in the Lokpanta oil shale with reference to PAAS is characteristic of continental island arc sediments.

(a)

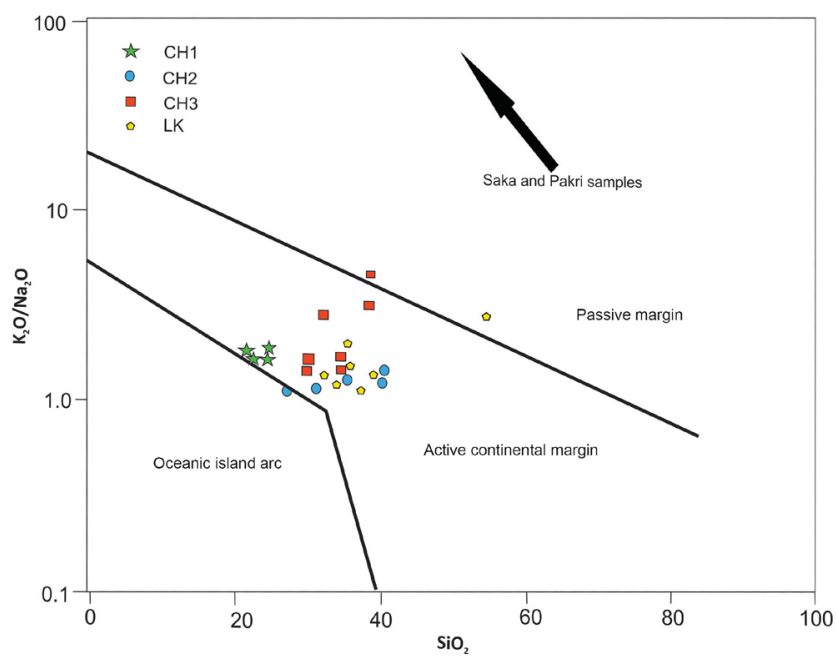

(b)

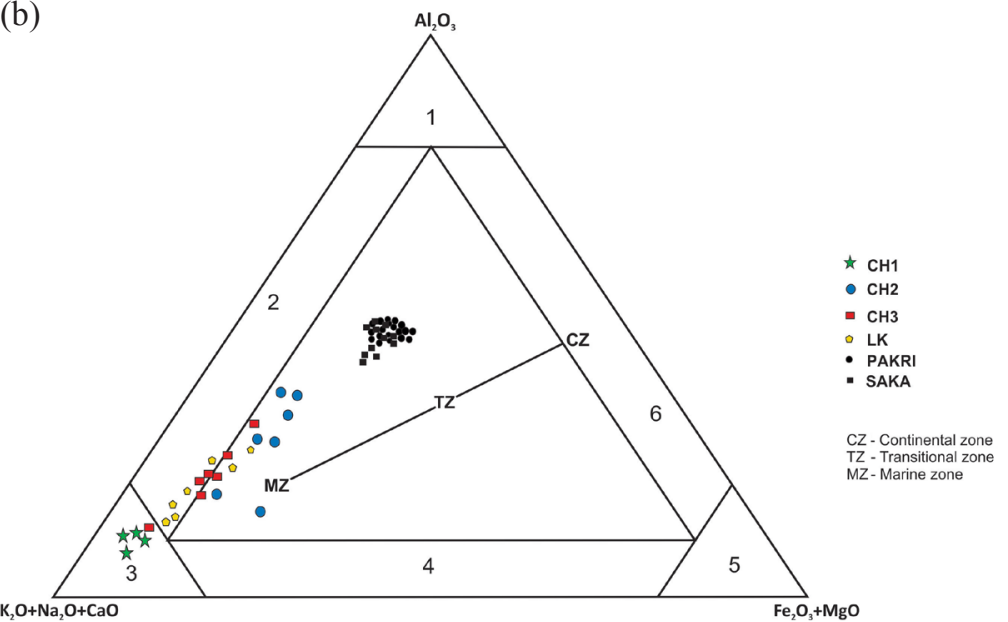


(c)

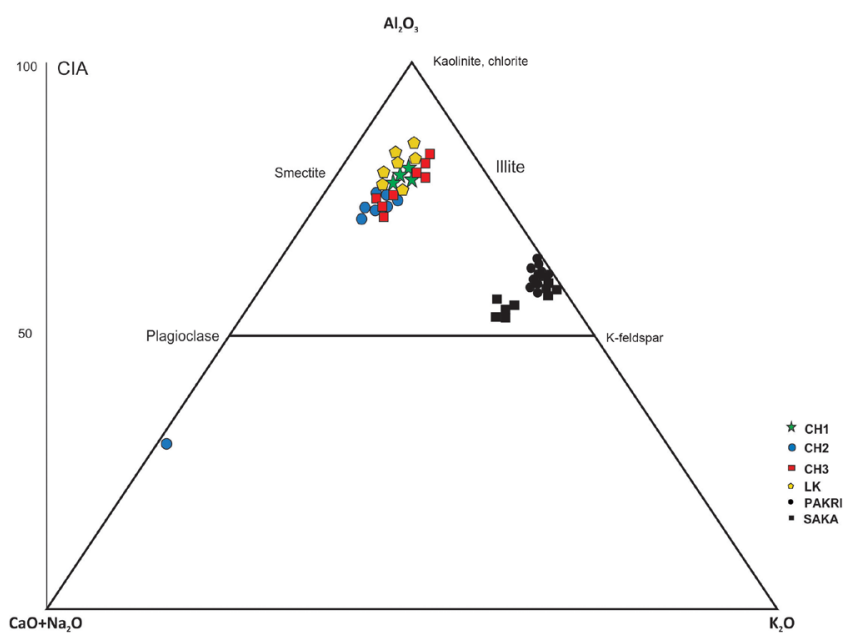

Fig. 5. (a) Tectonic discrimination diagrams for the Lokpanta oil shale and the Estonian graptolite argillite (after [32]), (b) a ternary plot for distinguishing the environment of deposition (after [36]), (c) A-CN-K $\left(\mathrm{Al}_{2} \mathrm{O}_{3}-\mathrm{CaO}+\mathrm{Na}_{2} \mathrm{O}-\mathrm{K}_{2} \mathrm{O}\right)$ ternary plot showing the degree of weathering of the Lokpanta oil shale and the Estonian graptolite argillite samples (after [38, 39]). Symbols as in Figures 3 and 4.

The discrimination diagram constructed by Bathia [34] was also studied to understand the tectonic setting of the Lokpanta OS. This diagram is based on the relationship between $\mathrm{TiO}_{2}$ and $\mathrm{Fe}_{2} \mathrm{O}_{3}+\mathrm{MgO}$ (not shown). A majority of the oil shale samples did not plot within any indicated field, only four samples plotted in the passive margin field and five in the continental island arc. However, this discrimination diagram has been found to have a minor success in discriminating sediments from active continental margins [35].

The chemical classification (AKF diagram) proposed by Englund and Jørgensen [36] was used to study the depositional environment of the Lokpanta oil shale. This discriminant plot uses major oxides $\left(\mathrm{Al}_{2} \mathrm{O}_{3}-\mathrm{K}_{2} \mathrm{O}+\right.$ $\mathrm{Na}_{2} \mathrm{O}+\mathrm{CaO}-\mathrm{Fe}_{2} \mathrm{O}_{3}+\mathrm{MgO}$; Fig 5b) to assign clastic sediments to continental, transitional and marine environments. The studied samples fall mainly in marine environment zones (Fig. 5b). The samples from drill core $\mathrm{CH} 1$ and one sample from $\mathrm{CH} 3$ tend to fall in the marine carbonaceous field, the rest of samples fall in the carbonaceous argillite field. The Estonian GA (samples from Pakri and Saka outcrops [9]) forms a tight cluster at the upper end of the Lokpanta oil shale in the transitional field (Fig. 5b).

The chemical index of alteration $\left(\mathrm{CIA}=\left[\mathrm{Al}_{2} \mathrm{O}_{3} /\left(\mathrm{Al}_{2} \mathrm{O}_{3}+\mathrm{CaO} *+\mathrm{Na}_{2} \mathrm{O}+\right.\right.\right.$ $\left.\left.\mathrm{K}_{2} \mathrm{O}\right)\right] \times 100$ ) (as calculated in molar values) and a similar index $\left(\mathrm{CIA}_{(\mathrm{molar})}=\right.$ $\mathrm{Al}_{2} \mathrm{O}_{3 \text { (molar) }} /\left(\mathrm{CaO}^{*}{ }_{\text {(molar) }}+\mathrm{Na}_{2} \mathrm{O}_{\text {(molar) }}+\mathrm{K}_{2} \mathrm{O}_{\text {(molar) }}\right)$ can be used to reflect 
paleoclimatic conditions. $\mathrm{CaO}^{*}$ represents the amount of $\mathrm{CaO}$ incorporated into the silicate fraction of the rock. It is calculated using the equation $\mathrm{CaO}^{*}=$ $\mathrm{CaO}-\left(10 / 3 \times \mathrm{P}_{2} \mathrm{O}_{5}\right)$ to correct the content of $\mathrm{P}_{2} \mathrm{O}_{5}$ (as apatite). If the mole fraction of $\mathrm{CaO}$ is greater than that of $\mathrm{Na}_{2} \mathrm{O}$, then $\mathrm{CaO}^{*}$ is equal to the amount of $\mathrm{Na}_{2} \mathrm{O}$. Otherwise, $\mathrm{CaO} *$ is equal to $\mathrm{CaO}$ [37]. Generally, CIA values between 65 and 85 correspond to a warm and humid climate, whereas values between 85 and 100 correspond to a humid subtropical or tropical climate [37]. The CIA of the Lokpanta OS varies between 70 and 80, while the Estonian GA's CIA is 55-65. These values suggest a warm and humid climate in both cases. In the $\mathrm{CaO}+\mathrm{Na}_{2} \mathrm{O}-\mathrm{Al}_{2} \mathrm{O}_{3}-\mathrm{K}_{2} \mathrm{O}$ plot $[38,39]$, the Lokpanta OS falls in the upper part of the ternary diagram (smectite-illite fields) as an elongated group on the line of $\mathrm{CaO}+\mathrm{Na}_{2} \mathrm{O}-\mathrm{Al}_{2} \mathrm{O}_{3}$ concentrations (Fig. 5c). The Estonian GA plots in a distinctive field close to the K-feldspars section (Fig. 5c).

The trace elements $\mathrm{Sr}$ and $\mathrm{Ba}$ and their ratios may be good indicators for distinguishing the salinity conditions of sedimentary basins. The $\mathrm{Sr} / \mathrm{Ba}$ ratio in freshwater sediments is mostly less than 1 and in marine sediments greater than 1 [37]. In lacustrine environments without seawater intrusion, the $\mathrm{Sr} / \mathrm{Ba}$ ratio between 0.5 and 1 indicates brackish water, while the ratio exceeding 1.0 suggests salty lake water in an arid climate [40,41]. Usually, the Lokpanta OS has the $\mathrm{Sr} / \mathrm{Ba}$ ratio above 1 , however, samples from drill core $\mathrm{CH} 2$ and two samples from drill core $\mathrm{CH} 3$ have $\mathrm{Sr} / \mathrm{Ba}$ ratios below or around 1 (variation from 0.47 to 1.02 ; not shown). The latter values may indicate a brackish water regime or the changing salinity in the basin. The Estonian GA has $\mathrm{Sr} / \mathrm{Ba}$ values of tight grouping between 0.1 and 0.2 , which indicates a freshwater environment or an environment of very low salinity in both the eastern and western zones of the deposit.

\subsection{Paleoredox conditions}

Trace elements are commonly used as paleoredox proxies in siliciclastic rocks. $\mathrm{U} / \mathrm{Th}$ ratio has been used as a measure of redox conditions in shales [42]. $\mathrm{U}$ is sensitive to redox conditions and is concentrated in anoxic environments where it occurs as immobile $\mathrm{U}^{4+}$, whereas it is depleted in oxic environments. On the other hand, the amount of Th in the depositional environment is not affected by its oxygen level. Nath et al. [42] suggested that the U/Th ratio less than 1.25 is indicative of oxic conditions while ratios greater than $1.25 \mathrm{imply}$ anoxic conditions. The U/Th ratio of the Lokpanta OS samples ranges widely, from 62 to 0.3 , the values of $58 \%$ of the samples being indicative of an anoxic environment. The range of U/Th ratios of the Estonian GA samples is also wide, from 1 to 51, while only two samples from Pakri (the western zone) show values below 1.25.

Jones and Manning [40] used Ni/Co ratio to measure the degree of anoxia. A Ni/Co ratio less than 5 was assigned to an oxygenated environment while a ratio greater than 5 indicated anoxic conditions. The $\mathrm{Ni} / \mathrm{Co}$ ratios of the 
Lokpanta OS samples range from 3.8 to 15 , averaging 8. Most samples fall in the dysoxic and suboxic/anoxic fields, only two samples fall in an oxygenated environment (Fig. 6a). The Ni/Co values of the Estonian GA samples from the western zone (Pakri) vary mainly between 5 and 9, while those of samples from the eastern zone (Saka) remain always below 5, referring to oxic conditions (Fig. 6a).

(a)

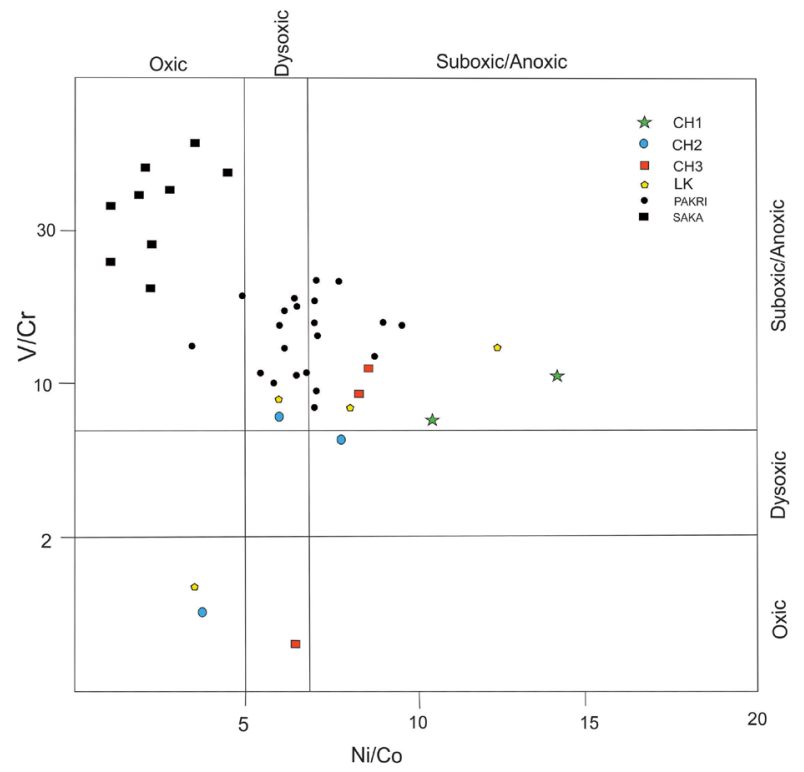

(b)

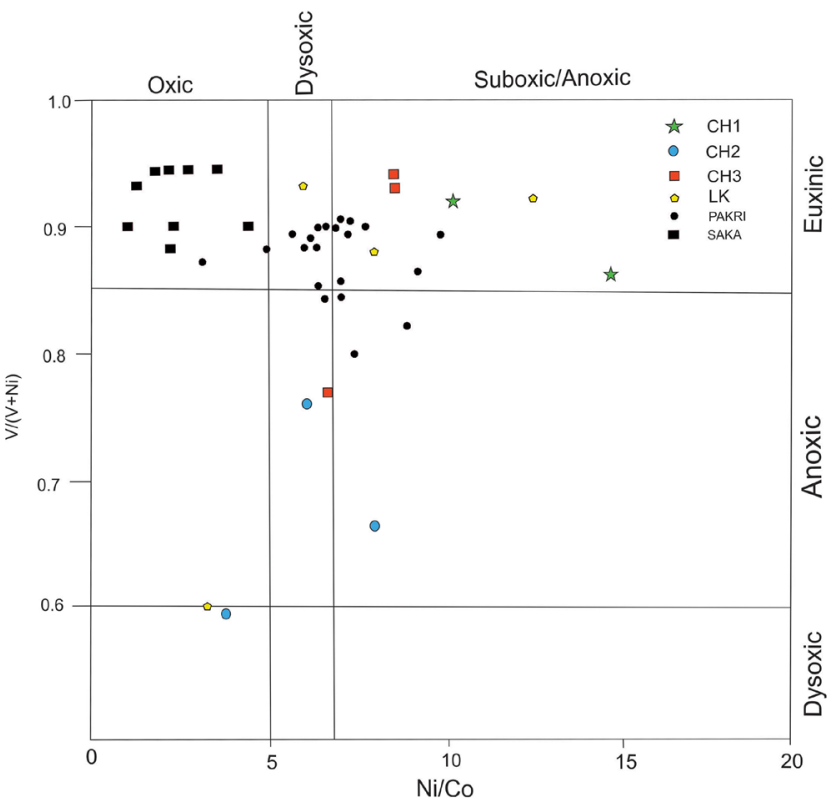

Fig. 6. (a) Trace elemental ratio plots for distinguishing redox conditions: $\mathrm{Ni} / \mathrm{Co}$ vs $\mathrm{V} / \mathrm{Cr}$ (after [40]), (b) Ni/Co vs V/(V+ Ni) (after [44]). Symbols as in Figures 3 and 4. 
$\mathrm{V} / \mathrm{Ni}$ ratio is used as a paleoredox proxy. $\mathrm{V}$ is more stable in an anoxic environment than $\mathrm{Ni}$. A V/Ni ratio greater than 3 suggests that sediments were deposited in an anoxic environment. On the other hand, a ratio between 1.9 and 3 suggests deposition in an oxygen-rich environment [43]. The $\mathrm{V} / \mathrm{Ni}$ of the Lokpanta OS is from 1.4 to 16 , with three samples having this ratio below 3 . This is in agreement with other redox ratios used in the paper, which imply deposition in an oxygen-deficient environment. All the Estonian GA samples show $\mathrm{V} / \mathrm{Ni}$ ratios higher than 3 (4-17), suggesting anoxic conditions.

$\mathrm{V} /(\mathrm{V}+\mathrm{Ni})$ and $\mathrm{V} /(\mathrm{V}+\mathrm{Cr})$ ratios can also be used as a measure of the degree of anoxia. It has been suggested that a $\mathrm{V} /(\mathrm{V}+\mathrm{Ni})$ greater than 0.8 and a $\mathrm{V} /(\mathrm{V}+\mathrm{Cr})$ above 0.6 should be indicative of strongly reducing conditions [44]. In case of the Lokpanta OS, such ratios refer to a strongly reducing paleoenvironment. This is a major difference between the Lokpanta OS and the Estonian GA. The Ni/Co ratios of GA samples from East Estonia correspond to oxic conditions, while samples from Pakri, West Estonia plot mostly in the dysoxic field, some falling in the suboxic/anoxic field. At the same time, the $\mathrm{V} / \mathrm{Cr}$ and $\mathrm{V} /(\mathrm{V}+\mathrm{Ni})$ ratios of the Estonian GA are in accordance with the values characteristic of suboxic/anoxic and euxinic environments, respectively (Figs. 6a and 6b).

In an oxygen-rich environment, $\mathrm{Mn}$ forms highly insoluble $\mathrm{Mn}^{3+}$ or $\mathrm{Mn}^{4+}$ hydroxides or oxides, whereas in an anoxic water column the soluble $\mathrm{Mn}^{2+}$ may dissolve and diffuse upward in the anoxic water. This may result in $\mathrm{Mn}$ depletion in the sediments. Thus, the concentration of Mn is usually low in sediments deposited under reducing conditions [45]. The Mn concentration of the Lokpanta OS samples is from 113 to $1072 \mathrm{ppm}$, averaging $382 \mathrm{ppm}$ (Table 4). Only one sample from $\mathrm{CH} 2-7.5$ shows an exceptionally high concentration of $\mathrm{Mn}$. This is generally interpreted to mean deposition under anoxic conditions. The Mn concentration in the Estonian GA is usally low, between 80 and 380, with an average of 177 , suggesting also anoxic depositional conditions.

\section{Conclusions}

A detailed inorganic geochemical study has been carried out on the Lokpanta oil shale with a view to reconstructing the paleoredox conditions, tectonic settings and depositional environment. The mineral phases in the oil shale include calcite, quartz, dolomite, feldspar, illite, kaolinite, halloysite, pyrite and gypsum, as well as a trace amount of anatase. The Lokpanta oil shale shows little variation in geochemistry. It has been found to be depleted in trace elements $\mathrm{Ba}$ and $\mathrm{Rb}$ and major compounds except $\mathrm{CaO}$, and is enriched in Mo (10-20 times), Sb (20 times), As (2-10 times), V (2-8 times), Zn (2-8 times), Ni (2-4 times) and U (2-3 times) with reference to the Post-Archean Australian Shale. These enrichments are, however, in most cases lower than those of the Estonian graptolite argillite. Most likely, the Lokpanta oil shale 
will not be a target for metal production in the near future. However, as coproducts, some metals in the oil shale such as Mo, Sb, V and Ni may be of interest when the extraction technology improves.

Trace element ratios (U/Th, Ni/Co, $\mathrm{V} / \mathrm{Ni}, \mathrm{V} /(\mathrm{V}+\mathrm{Ni}), \mathrm{V} /(\mathrm{V}+\mathrm{Cr})$ ) indicate that the Lokpanta oil shale was deposited in an anoxic environment. Discriminant diagrams also suggest that the oil shale was deposited in an active continental margin setting and a transitional to marine environment.

There is a fair to moderate similarity in the studied paleoenvironmental conditions between the Lokpanta oil shale and the Estonian graptolite argillite, suggesting that other factors such as sediment provenance may have played a significant role in geochemical composition and the observed similarity in elemental enrichment trends between both rocks.

\section{REFERENCES}

1. World Energy Council. World Energy Resources 2016, Summary, 16.

2. Ekweozor, C. M., Unomah, G. I. First discovery of oil shale in the Benue Trough, Nigeria. Fuel, 1990, 69(4), 502-508.

3. Fatoye, F. B, Gideon, Y. B. Geology and mineral resources of the Lower Benue Trough, Nigeria. Adv. Appl. Sci. Res., 2013, 4(6), 21-28.

4. Ehinola, O. A. Biostratigraphy and depositional environment of the oil shale deposit in the Abakaliki fold belt, Southeastern Nigeria. Oil Shale, 2010, 27(2), 99-125.

5. Amajor, L. C. Major and trace element geochemistry of Albian and Turonian shales from the Southern Benue trough, Nigeria. J. Afr. Earth Sci., 1987, 6(5), 633-641.

6. Ehinola, O. A., Sonibare, O. O., Akanbi, O. A. Economic evaluation, recovery techniques and environmental implications of the oil shale deposit in the Abakaliki anticlinorium, Southeastern Nigeria. Oil Shale, 2005, 22(1), 5-19.

7. Akande, S. O., Ojo, O. J., Adekeye, O. A, Egenhoff, S. O., Obaje, N. G., Erdtman, B. D. Stratigraphic evolution and petroleum potential of Middle Cretaceous sediments in the Lower and Middle Benue Trough, Nigeria: Insights from new source rock facies evaluation. Petroleum Technology Development Journal (PTDJ), 2011, 1, 1-34.

8. Sonibare, O. O., Jacob, D. E., Ward, C. R., Foley, S. F. Mineral and trace element composition of the Lokpanta oil shale in the Lower Benue Trough, Nigeria. Fuel., 2011, 90(9), 2843-2849.

9. Voolma, M., Soesoo, A., Hade, S., Hints, R., Kallaste, T. Geochemical heterogeneity of the Estonian graptolite argillite. Oil Shale, 2013, 30(3), 377-401.

10. Olade, M. A. Evolution of Nigeria's Benue Trough (Aulacogen): a tectonic model. Geol. Mag., 1975, 112(6), 575-583.

11. McCurry, P. The geology of the Precambrian to Lower Paleozoic rocks of Northern Nigeria, a review. In: Geology of Nigeria (Kogbe, C. A., ed.), 1976, 
15-39. Elizabethan Pub. Co., Lagos.

12. Carter, J. D., Barber, W., Tait, E. A. The geology of parts of Adamawa, Bauchi and Borno provinces in Northeastern Nigeria. Bull. Geol. Surv. Nigeria, 1963, 30, $1-109$.

13. Wozny, E., Kogbe, C. A. Further evidence of marine Cenomanian, lower Turonian and Maastrichtian in the Upper Benue basin of Nigeria (West Africa). Cretac. Res., 1983, 4(1), 95-99.

14. Reyment, R. A. Aspects of the Geology of Nigeria. Ibadan University Press, Ibadan, 1965, 145.

15. Nwachukwu, S. O. The tectonic evolution of the southern portion of the Benue Trough, Nigeria. Geol. Mag., 1972, 109(5), 411-419.

16. Amajor, L. C. The Cenomanian hiatus in the Southern Benue Trough, Nigeria. Geol. Mag., 1985, 122(1), 39-50.

17. Adighije, C. Gravity study of Lower Benue Trough, Nigeria. Geol. Mag., 1981, 118(1), 59-67.

18. Offodile, M. E. A review of the geology of the Cretaceous of the Benue Trough. In: Geology of Nigeria (Kogbe, C. A., ed.), 1976, 319-330. Elizabethan Pub. Co., Lagos.

19. Weibel, R. Effects of burial on the clay assemblages in the Triassic Skagerrak Formation, Denmark. Clay Miner., 1999, 34(4), 619-635.

20. Hade, S., Soesoo, A. Estonian graptolite argillites revisited: a future resource? Oil Shale, 2014, 31(1), 4-18.

21. Soesoo, A., Hade, S. Black shales of Estonia: moving towards a FennoscandianBaltoscandian database. Transactions of Karelian Research Centre of Russian Academy of Sciences: Precambrian Geology, 2014, 1, 103-114.

22. Hints, R., Soesoo, A., Voolma, M., Tarros, S., Kallaste, T., Hade, S. Centimetrescale variability of redox-sensitive elements in Tremadocian black shales from the eastern Baltic Palaeobasin. Estonian J. Earth Sci., 2014, 63(4), 233-239.

23. Hints, R., Hade, S., Soesoo, A., Voolma, M. Depositional framework of the East Baltic Tremadocian black shale revisited. GFF, 2014, 136(3), 464-482.

24. Soesoo, A., Puura, V., Kirs, J., Petersell, V., Niin, M., All, T. Outlines of the Precambrian basement of Estonia. Proc. Estonian Acad. Sci. Geol., 2004, 53(3), 149-164.

25. Pukkonen, E., Rammo, M. Distribution of molybdenum and uranium in the Tremadoc graptolitic argillite (Dictyonema shale) of North-Western Estonia. Bull. Geol. Surv. Estonia, 1992, 2(1), 3-15.

26. Petersell, V., Mineyev, D., Loog, A. Mineralogy and geochemistry of obolus sandstones and dictyonema shale of North Estonia. Acta et Comment. Univ. Tartu., Tartu, 1981, 561, 30-49 (in Russian).

27. Veski, R., Palu, V. Investigation of Dictyonema oil shale and its natural and artificial transformation products by a vankrevelenogram. Oil Shale, 2003, 20(3), 265-281.

28. Lippmaa, E., Maremäe, E. Uranium production from the local Dictyonema shale in North-East Estonia. Oil Shale, 2000, 17(4), 387-394. 
29. Soesoo, A., Hade, S. Metalliferous organic-rich shales of Baltoscandia - a future resource or environmental/ecological problem. Archiv Euro Eco, 2012, 2(1), $11-14$.

30. Taylor, S. R., McLennan, S. M. The Continental Crust: Its Composition and Evolution. Blackwell, Oxford, 1985, 312.

31. Petters, S. W., Ekweozor, C. M. Petroleum geology of Benue trough and southeastern Chad basin. AAPG Bull., 1982, 66(8), 1141-1149.

32. Roser, B. P., Korsch, R. J. Determination of tectonic setting of sandstonemudstone suites using $\mathrm{SiO}_{2}$ content and $\mathrm{K}_{2} \mathrm{O} / \mathrm{Na}_{2} \mathrm{O}$ ratio. J. Geol., 1986, 94(5), 635-650.

33. Adeigbe, O. C., Jimoh, Y. A. Geochemical fingerprints; Implication for provenance, tectonic and depositional settings of Lower Benue Trough sequence, Southeastern Nigeria. J. Environ. Earth Sci., 2013, 3(10), 115-140.

34. Bhatia, M. R. Plate tectonics and geochemical composition of sandstone. J. Geol., 1983, 91(6), 611-627.

35. Armstrong-Altrin, J. S., Verma, S. P. Critical evaluation of six tectonic setting discrimination diagrams using geochemical data of Neogene sediments from known tectonic settings. Sediment. Geol., 2005, 177(1-2), 115-129.

36. Englund, J.-O., Jørgensen, P. A chemical classification system for argillaceous sediments and factors affecting their composition. Geol. Foren. Stock. For., 1973, 95(1), 87-97.

37. Meng, Q. T., Liu, Z. J., Sun, P. C., Xu, Y. B., Li, F., Bai, Y. Y., Xie, W. Q., Deng, S., Song, S., Wang, K. B., Xu, C. Characteristics and accumulation of Middle Jurassic oil shale in the Yuqia area, Northern Qaidam Basin, Northwest China. Oil Shale, 2018, 35(1), 1-25.

38. Nesbitt, H. W., Young, G. M. Early Proterozoic climates and plate motions inferred from major element chemistry of lutites. Nature, 1982, 299(5885), 715-717.

39. Harnois, L. The CIW index: A new chemical index of weathering. Sediment. Geol., 1988, 55(3), 319-322.

40. Jones, B., Manning, D. A. C. Comparison of geochemical indices used for the interpretation of palaeoredox conditions in ancient mudstones. Chem. Geol, 1994, 111(1-4), 111-129.

41. Luo, Q. Y., Zhong, N. N., Zhu, L., Wang, Y. N., Qin, J., Qi, L., Zhang, Y., Ma, Y. Correlation of burial organic carbon and paleoproductivity in the Mesoproterozoic Hongshuizhuang Formation, northern North China. Chinese Sci. Bull., 2013, 58(11), 1299-1309.

42. Nath, B. N., Bau, M., Rao, B. R., Rao, Ch. M. Trace and rare earth elemental variation in Arabian Sea sediments through a transect across the oxygen minimum zone. Geochim. Cosmochim. Acta, 1997, 61(12), 2375-2388.

43. Galarraga, F., Reategui, K., Martïnez, A., Martínez, M., Llamas, J. F., Marquez, G. V/Ni ratio as a parameter in palaeoenvironmental characterisation of nonmature medium-crude oils from several Latin American basins. J. Petrol. Sci. Eng., 2008, 61(1), 9-14. 
44. Hatch, J. R., Leventhal, J. S. Relationship between inferred redox potential of the depositional environment and geochemistry of the Upper Pennsylvanian (Missourian) Stark Shale Member of the Dennis Limestone, Wabaunsee County, Kansas, U.S.A. Chem. Geol., 1992, 99(1-3), 65-82.

45. Tribovillard, N.,Algeo, T. J., Lyons, T., Riboulleau, A. Trace metals as paleoredox and paleoproductivity proxies: An update. Chem. Geol., 2006, 232(1-2), 12-32. 